\title{
Drivers of Change in Socio-Ecological Production Landscapes: Implications for Better Management
}

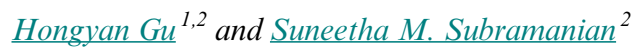

\begin{abstract}
The term socio-ecological production landscapes (SEPLs) has recently gained currency in conservation circles because of a recognized need to look beyond protected areas to the management of human-influenced landscapes and ecosystems. We have drawn on a variety of case studies from Asia and other parts of the world to understand the underlying driving forces that have led to the need for greater awareness and sustainable management of SEPLs. We have analyzed the drivers of these changes from sociopolitical, legal, economic, and socio-cultural perspectives. The analysis shows that SEPLs contribute to local, national, and global economies, and their production and harvesting processes are subject to external demands and pressures. Policy makers should recognize the wide range and diverse values of SEPLs and incorporate these values into broader policy considerations. We have also provided some suggestions for future studies.
\end{abstract}

Key Words: case study; conservation; cultural landscapes; drivers of change; ecosystem approach; resilience

\section{INTRODUCTION}

There is growing recognition in conservation circles that nature and culture are intricately linked and that traditional protected areas alone cannot halt global biodiversity loss (Phillips 1998, Brown et al. 2005, Mathur and Sinha 2008, Mora and Sale 2011). In addition, global demand for food and other resources is on the rise, which calls for a more integrated approach to the conservation and sustainable use of biodiversity (Mukherjee and Borad 2004, Iftekhar 2006, Harvey et al. 2008). Against this background, a number of new approaches and initiatives have emerged over the past decade or so, including the protected landscape approach of the International Union for Conservation of Nature, the Globally Important Agricultural Heritage Systems Initiative of the Food and Agriculture Organization of the United Nations (FAO), and the European Landscape Convention. More recently, the Ministry of the Environment, Japan, and the United Nations University Institute for the Advanced Study of Sustainability jointly launched the Satoyama Initiative, with the aim of promoting sustainable use of forests, agricultural land, pastoral land, and other types of ecosystems within socioecological production landscapes (SEPLs), as well as to enhance their resilience in the face of natural disasters, climate change, and other challenges.

The term SEPLs derives from the work of the Japan Satoyama Satoumi Assessment, which analyzed changes occurring in Japan's terrestrial and marine ecosystems and explored alternative future scenarios by using the Millennium Ecosystem Assessment framework (Duraiappah et al. 2012). In Japanese, satoyama refers to secondary woodlands adjacent to rural settlements, and satoumi refers to coastal areas sustainably managed by fishing communities. Recognizing that similar landscapes and seascapes can be found in many parts of the world, the Satoyama Initiative has begun to use SEPLs as a more general term to describe its target areas. The Satoyama Initiative was recognized at the 10th meeting of the Conference of the Parties to the Convention on Biological Diversity (CBD) in 2010, together with the launch of the International Partnership for the Satoyama Initiative (IPSI).
By definition, SEPLs refers to dynamic mosaics of habitats and land uses that have been shaped over the years by interactions between people and nature in ways that maintain biodiversity and provide humans with goods and services needed for their wellbeing. Although SEPLs is a relatively new term, it shares a basic premise with the existing literature on social-ecological systems and resilience thinking (e.g., Berkes et al. 2003, Folke 2006, Walker et al. 2006), which holds that social and ecological systems are coupled, and that adaptive management is needed to address ecosystem change. Our purpose, however, is not to present a new conceptual framework for the analysis of social-ecological systems. What we intend to do is to draw insights from the case studies of the Satoyama Initiative and to understand the driving forces underpinning changes in SEPLs as well as their implications for sustainable landscape management. A preliminary review of case studies contributed by IPSI members and other researchers suggests that SEPLs have undergone significant changes over the past few decades, and measures are urgently needed to address their degradation and loss. We selected 16 of these case studies based on the variety of ecosystem types and the magnitude of change as reflected in the way SEPLs are managed and conserved. Taking into account the diversity of SEPLs, we have grouped them into 5 categories, namely forest ecosystems, rice agro-ecosystems, inland water systems, agropastoralism, and mountain ecosystems. Table 1 provides an overview of these case studies.

It should be noted that SEPLs provide ecosystem services not only for local communities but also for a larger population outside their boundaries. Indeed, the production and harvesting processes of SEPLs are increasingly influenced by external demands and pressures and by policy decisions made at the national and international levels. To highlight such linkages, Table 1 includes a column that describes the socio-political context in which a particular SEPL has evolved over the past five decades, as well as major food and agricultural commodities for both domestic and export markets. FAO statistics (http://faostat.fao.org/) provide the basis for the analysis of production and export trends. 
Table 1. Overview of case studies. SEPL $=$ socio-ecological production landscapes.

\begin{tabular}{ll}
\hline \hline Case Studies & Country Information \\
$\begin{array}{l}\text { Forest ecosystems } \\
\text { Role and involvement of } \\
\text { the commune council in } \\
\text { community forestry }\end{array}$ & $\begin{array}{l}\text { Cambodia } \\
\text { Socio-political context: A former French colony, gained } \\
\text { independence in 1953, civil war, genocide and armed }\end{array}$ \\
$\begin{array}{l}\text { Ta Thmos Puan (Marady } \\
\text { et al. 2012) }\end{array}$ & $\begin{array}{l}\text { conflict (1970-1991), postwar reconstruction toward } \\
\text { decentralization and democratization } \\
\text { Major food and agricultural commodities: Rice, cassava, } \\
\text { indigenous cattle meat, pig meat, maize } \\
\text { Major agricultural export commodities: Soybeans, rubber, } \\
\text { milled rice, maize, palm oil }\end{array}$ \\
$\begin{array}{l}\text { Nepal } \\
\text { The Patale community } \\
\text { forest in Lamatar Village } \\
\text { Development Committee, }\end{array}$ & $\begin{array}{l}\text { Socio-political context: A parliamentary monarchy since } \\
\text { 1990, civil war (1996-2006) between government forces } \\
\text { Lalitpur District (Adhikari Maoist rebels } \\
\text { and }\end{array}$ \\
Major food and agricultural commodities: Rice, vegetables, \\
indigenous buffalo meat, potatoes
\end{tabular}

Characteristics of the SEPL

Landscapes: Mountainous

Major products: Rice

Drivers of change: International donors seek to use aid conditionality to promote the legalization of the forestry sector and community forestry development. First nationwide commune/sangkat council elections were held in 2002, and these councils play an important role in implementing community forestry activities.

Landscapes: Mountainous

Major products: Rice

Drivers of change: By the end of the 1980s, the demand for a more participatory, bottom-up approach to development was indigenous buffalo meat, potatoes

Major agricultural export commodities: Lentils, nutmeg, mace and cardamom, tea, wheat

mounting, which led to the adoption of community forest use groups (CFUGs). However, civil war has relegated community forestry to a lower level of political priority, and the proposed amendments to the Forest Act of 1993 may constrain the autonomy of CFUGs and increase bureaucratic control over forest resources (Fisher 2010, Sunam et al. 2010).

Forest management through community-based forest enterprises in Ixtlan de Juarez, Oaxaca (Matsuzaki and Wong 2010)

\section{Mexico}

Socio-political context: A former Spanish colony, gained independence in 1821. Legal framework was established in the 1990s for multiculturalism and indigenous peoples' rights.

Major food and agricultural commodities: Cattle meat, chicken meat, sugar cane, maize, tomatoes, green chillies and peppers, mangoes, avocado

Major agricultural export commodities: Barley beer, tomatoes, avocado, green chillies and peppers

Kandyan homegardens (Pushpakumara et al. 2010)

The Owita agro-ecosystem (Wijisekara and Hunter 2010)

Rice agro-ecosystem

Natural resource

Cambodia

management in the critical Socio-political context: As mentioned above

habitat of Western Siem

Pang

Major food and agricultural commodities: As mentioned above

(Costello and Vorsak 2011) Major agricultural export commodities: As mentioned above

Sri Lanka

Socio-political context: A former British colony, gained independence in 1948. The postcolonial governments have maintained a strong policy focus on promoting smallholder agriculture particularly in relation to irrigation and rice production. The Sri Lankan civil war (1983-2009) caused hardships to the population, the economy, and the environment of the country. coconut, natural rubber, chicken meat Major agricultural export commodities: Tea, rubber, cinnamon, desiccated coconut Major food and agricultural commodities: Rice, tea,

Landscapes: Mountainous

Major products: Maize, sugar cane, tomatoes

Drivers of change: Until recently the incentives for introducing community-based forest management remained perverse because indigenous communities were often seen as an impediment to Mexico's modernization and its economic integration with the rest of the world (Diego Quintana et al. 1998). The electoral Usos y Costmbres reforms were carried out in the state of Oaxaca between 1992 and 1998, which gave local communities the autonomy to decide on the use and benefit-sharing of forest resources.

Landscapes: Wet zone, lowland valleys

Major products: Food items (e.g., sweet potato, taro, yam), fruits, ornamentals, vegetables, medicinal plants, timber trees, spices, cash crops (e.g., avocado, cocoa, cloves, coconut) Drivers of change: urbanization, population growth and inappropriate land development pose great threats to the longterm survival of Kandyan homegardens. Most conservation programmes in Sri Lanka now include homegardens as a component.

Landscapes: Wet zone, low-lying areas

Major products: Rice, betel leaves, root and tubers (taro, innala, yams, sweet potato), leafy vegetables, brinjal, cucumber, bitter gourd, yardlong beans, banana Drivers of change: The Owita agro-ecosystem has been neglected since Sri Lanka's shift to a market economy in 1978. Recent government policies on local food production have provided opportunities to revive the Owita system.

Landscapes: Transborder protected forest area with trapaengs (seasonal pools)

Major products: Rice

Drivers of change: Since postwar reconstruction began in the early 1990s, the Cambodian government has sought to capitalize on its forest resources by granting land concessions to agricultural and extraction industries. Under such circumstances, sizeable areas of agricultural land have been converted for commercial production of timber and sugar. Birdlife Cambodia, in collaboration with the Forestry Administration, has initiated several projects aimed at strengthening community-based natural resource management. 
Waterbird conservation promotes important energy flow between rice paddies and nearby Important Bird Areas (Mugica-Valdé;s et al. 2011)

Reintroduction project of the Oriental White Stork (Ciconia boyciana) in Toyooka City, Hyogo Prefecture (Ohsako 2010)

Inland water systems Small-scale catchment management in Chindozwa (Nakayama 2010)

Local livelihood in the Lower Songkhram Basin (Ministry of Natural Resources and Environment, Thailand 2011)

Promoting comanagement of Eastern African wetlands and lower floodplains (KENWEB 2011)
Cuba

Socio-political context: A former Spanish colony, gained independence in 1898.

Major food and agricultural commodities: Sugar cane, tomatoes, pig meat, mangoes, cow milk Major agricultural export commodities: Sugar, cigars, orange juice, grapefruit juice
Landscapes: Island country with tropical climate

Major products: Sugar cane, rice, tomatoes

Drivers of change: The export-oriented, capital intensive model of development that emerged before and after the Cuban Revolution (1953-1959) created problems of trade dependency, inequitable land tenure, food insecurity, and environmental degradation. The model was forced to shift toward organic farming following the collapse of Cuba's trading partners in the Soviet bloc. The ecology group of the University of Havana is working with farmers through education and training toward achieving the dual goal of minimizing rice loss while enhancing the quality of bird habitats and food security.

Landscapes: Archipelago, mountainous

Major products: Rice

Drivers of change: Wartime logging and postwar land-use changes led to a drastic decline in the population of Oriental White Storks. The reintroduction project began in 1955 and achieved its first success in 1989. The local government introduced Oriental White Stork friendly farming methods to promote organic farming. Branding and certification system (1955-1975) was marked by the decline of the agricultural sector. Since the 1990s, there has been growing concern over the aging of rural population and the possible threat to food security.

Major food and agricultural commodities: Rice, cow milk, pig meat, chicken meat, apples Major agricultural export commodities: Cigarettes, pastry, was also introduced, and these products can be sold at higher infant food, apples prices.

Malawi

Socio-political context: A former British colony, gained

Landscapes: Landlocked country, Malawi Lake's catchment area

independence in 1964. The rapid growth of the plantation Major products: Cotton, tobacco, maize, cassava, fishery sector (notably tobacco) led to the alienation of customary land to larger landowners. Recent development policies seek to address this bias by placing more emphasis on rural livelihood improvement and poverty reduction.

Major food and agricultural commodities: Potatoes, maize, cassava, tobacco, bananas

Major agricultural export commodities: Palm oil, rubber, cocoa butter, pastry

Thailand

Socio-political context: Since the early 1950s, government policies and foreign aid were directed toward rural development and pacification of northeast Thailand through infrastructure investment. Thailand joined WTO in 1995.

Major food and agricultural commodities: Rice, natural rubber, cassava, sugar cane, mangoes

Major agricultural export commodities: Rice, natural rubber

Kenya

Socio-political context: A former British colony, gained independence in 1963. Irrigation projects have been a preferred policy option for modernizing agricultural production, minimizing food deficits, and imports and ameliorating the impacts of drought.

Major food and agricultural commodities: Cow milk, cattle meat, tea, maize, mangoes

Major agricultural export commodities: Tea, coffee, vegetables, cigarettes, tobacco
Drivers of change: Things started to change in the late 1980s because of growing concerns about deforestation, spurred by crop failure caused by the cassava mealy bug disaster and the concomitant clearing of new fields in the area. With the influx of temporary food aid, villagers have begun to substitute cassava with maize, and fishers have turned to more effective gear to earn more cash for maize purchase. Community-based conservation efforts such as reforestation have emerged. The combination of farm and nonfarm sources of income helps the fishing communities to adapt to adverse conditions. Landscapes: Riverine

Major products: Rice, fish

Drivers of change: Traditional subsistence farming has been gradually overtaken by more intensive agriculture oriented toward external markets, which has caused a notable decline in the productivity of the seasonally flooded forest.

Comanagement measures are being developed between multiple stakeholders for sustainable fisheries in the watershed (Khumsri et al. 2005).

Landscapes: Wetlands, floodplains

Major products: Mango, cashew, banana, maize, sorghum, sesame, rice, maize

Drivers of change: The intensive development of the upper catchment has brought about many environmental challenges in the Tana River Delta. The resulting productivity loss of the project will also cause negative impact on the wetlanddependent economies. KENWEB seeks to engage various stakeholders in developing comanagement strategy and action plans by recognizing the value of traditional management systems and empowering local communities in resource management. lower Tana River floodplains has seriously affected the

livelihoods of the riverine communities. A proposed biofuel 


\section{Agro-pastoralism} Integrating community development with the management of grasslands at Ke'erqin National Natural Reserve, Inner Mongolia (Liu et al. 2012)
China

Socio-political context: The world's most populous country, tension between development and conservation looms large. Ownership and stewardship are contested issues with the expansion of nature reserves in rural and peri-urban areas.

Major food and agricultural commodities: Pig meat, rice, wheat, tomatoes, apples

Major agricultural export commodities: Garlic, tomato paste, tea, apples, dry beans

How farmers in Kitui use wild and agricultural ecosystems to meet their nutritional needs (Morimoto et al. 2010)

\section{Kenya}

Socio-political context: Colonial policies restricted the movement of pastoral communities, and the sedentarization process continued after independence. Major food and agricultural commodities: As mentioned above.

Major agricultural export commodities: As mentioned above.

Landscapes: Semiarid temperate zone, grassland, native elm forest and wetlands

Major products: Maize, mung beans, livestock raising (sheep and cattle)

Drivers of change: Past reforms such as the Household Responsibility System have had limited effect in mitigating the "tragedy of the commons," and the growth-oriented development approach takes insufficient consideration of the carrying capacity and ecosystem integrity of the Inner Mongolian pasture ( $\mathrm{Li}$ et al. 2007, Wu and $\mathrm{Du}$ 2008). The UNEP/GEF Siberian Crane Wetland project sought to engage multiple stakeholders and enhance capacity building through training, participatory planning, and restoration of traditional culture.

Landscapes: Over two-thirds of the country is arid or semiarid Major products: Maize, beans, pigeon peas, cassava, sweet potatoes

Drivers of change: Sedentarization and recent forest conservation policies have limited the access and use of forest resources, which increases the vulnerability of the pastoral communities to climate stress (Owuor et al. 2011). To cope with drought, farmers have taken advantage of the spatial variations by having farms in different zones, and by accessing food and fodder produced in other agro-ecological zones through market and kinship networks.

Mountain ecosystems Role of traditional knowledge in strengthening SEPL in Ifugao Province (Daguitan 2012)

The Philippines

Socio-political context: A former colony of Spain and the U.S., gained independence in 1946. About $15-20 \%$ of its population is recognized as indigenous

Major food and agricultural commodities: Rice, pig meat, bananas, coconuts, tropical fruits

Major agricultural export commodities: Coconut oil, bananas, pineapples

Peru

Socio-political context: A former Spanish colony, gained independence in 1821. Its agrarian system consists of plantations on the coast as well as large estates and peasant communities in the highlands.

Major food and agricultural commodities: Chicken meat, rice, potatoes, cow milk, cattle meat

Major agricultural export commodities: Coffee, asparagus, grapes, dry chillies and peppers

Spain

Socio-political context: The process of decentralization and Europeanization has accelerated following Spain's transition to democracy in the late 1970s and accession to the European Economic Community in 1986. Great regional disparities can be found in Spain due to ethnoterritorial diversity.

Major food and agricultural commodities: Olives, pig meat grapes, cow milk, tomatoes, potatoes

Major agricultural export commodities: Wine, virgin olive oil, tangerines, oranges, pig meat
Landscapes: Archipelago, mountainous

Major products: Rice

Drivers of change: The postindependent government continued to enforce the stereotypes of the Igorots as being backward so as to justify resources-based development (McKay 2006). Following the enactment of the Indigenous Peoples' Act in 1997, various efforts have been made to promote greater understanding of indigenous knowledge systems and practices on natural resource management to engage communities in the formulation and implementation of development plans.

Landscapes: Western coastline, central highlands, and tropical Amazon jungle in the east

Major products: Rice, potatoes

Drivers of change: The 1980s and 1990s witnessed a wave of neoliberal reforms in Peru's agricultural sector, which led to the privatization of co-operatives, reduction of subsidies, and the participation of new actors (e.g., NGOs) in research and provision of information (Ortiz 2006). ANDES launched the Potato Park project in 2000 seeking to establish an alternative model to improve local livelihoods and conserve biocultural heritage.

Landscapes: Mountainous inland, banks and terraces on the coast

Major products: Wheat or rye, turnips, and potatoes

Drivers of change: The reorientation of agricultural activity toward dairy farming and forestry, combined with rural depopulation, land consolidation, and urban development, has contributed to the homogenization and simplification of the , Galician landscape. The Government of Galicia issued the Act on Landscape in 2008 and presented its landscape strategy in 2011, which constitutes an opportunity to identify, conserve, and promote the traditional landscapes as a means of fostering regional development and identity.

\section{SYNTHESIS OF THE CASE STUDIES}

We provide a synthesis of the case studies listed in Table 1 . We aim to draw the links between changes of SEPLs with external demands, pressures, and policy interventions and set the stage for the analysis of drivers of change.

\section{Forest ecosystems}

Forests provide important goods and services for human wellbeing. Participatory forest management strategies such as community forestry have been developed to improve rural livelihoods and forest ecosystems. They also serve as a tool for 
donor agencies to promote decentralization and alleviate poverty (Colfer and Capistrano 2005, Sunderlin 2006). In the cases of Cambodia and Nepal, new administrative units such as commune/sangkat councils and community forest user groups were introduced as a means to promote devolution of natural resource management to local communities. In practice, however, devolution of control over forests has been difficult in areas where commercially valuable timber can be grown and harvested (Davis 2005). By contrast, community-based forest enterprises have been relatively successful in the Ixtlán de Juárez municipality of Mexico's state of Oaxaca because the legal system recognizes and protects indigenous peoples' rights, and local communities are given the autonomy to decide on the use of forest resources and sharing of benefits arising from them. In Sri Lanka, traditional land-use systems such as Kandyan homegardens and the Owita agro-ecosystem have diminished over the past few decades because of urbanization, population growth, and the outbreak of civil war. In recent years, however, there has been a policy shift toward reviving traditional farming practices as a means of promoting food self-sufficiency and self-employment.

\section{Rice-field agro-ecosystems}

The worldwide decline in natural wetlands has led to a growing interest in the conservation value of rice fields as alternative habitats for wetland species. The case studies from Cambodia, Cuba, and Japan illustrate efforts being made by researchers, conservation groups, and local government to address this challenge. Community-based natural resource management and organic farming represent alternative farming strategies to those that rely on the extensive use of agrochemicals, machinery, irrigation systems, and high-yielding varieties. However, the expansion of resource-driven markets has placed great pressure on forests, habitats, biodiversity, and people's livelihoods in Cambodia, making the maintenance of traditional land-use practices increasingly difficult. Cuba's move to organic farming was triggered by the collapse of major trading partners in the Soviet Bloc. It remains to be seen whether the Cuban government will be able to resist the reimposition of a capital-intensive, exportoriented agriculture in the face of political and economic pressure from the United States and the global trading system (Gonzalez 2003). In Toyooka City, Japan, the project to reintroduce the Oriental White Stork (Ciconia boyciana) can be considered part of Japan's rural revitalization movement, which aims to address the problems of depopulation and the increase in degraded and abandoned farmland.

\section{Inland water systems}

Inland water systems such as lakes, rivers, and wetlands are multiple-use common pool resources "that are used for different types of extractive and non-extractive purposes by different stakeholder groups and are managed under a mixture of property right regimes" (Steins and Edwards 1999:242). The case studies of Malawi, Thailand, and Kenya highlight the tensions caused by rapid development of fishing and other natural resource-based industries that are mostly oriented toward external markets, making it difficult to sustain traditional land-use practices. This has also resulted in the decline of productivity of the freshwater ecosystems on which local communities depend for their livelihoods. To address such problems, multiple stakeholders are working toward developing comanagement strategies, although many challenges remain, such as legal reforms, occupational opportunities/alternatives, and empowerment of local communities.

\section{Agro-pastoralism}

Pastoralist societies are facing unprecedented challenges posed by population growth, loss of communal herding lands, sedentarization, urban migration, and periodic dislocation caused by drought, famine, and civil war (Fratkin 1997). The case of China's Inner Mongolia Autonomous Region illustrates donor-supported efforts in promoting community-based natural resource management. Although some progress has been made, challenges remain as to how to rebuild the traditional culture and social capital that have been dissipated because of development interventions and market forces. In Kenya's Kitui District, local communities have adapted traditional knowledge and institutions to cope with increasingly severe droughts. These institutions are deeply embedded in the local culture and are governed by customary rules through which traditional knowledge is created, preserved, and regenerated. Policy makers should build on these local strategies and interactions to develop flexible policies rather than imposing adaptation measures from above (Owuor et al. 2011).

\section{Mountain ecosystems}

Many communities living in hillside and mountainous areas are susceptible to poverty because of factors such as geographical isolation and lack of market access. The case studies of the Philippines and Peru demonstrate efforts being undertaken by nongovernmntal organizations (NGOs) to improve livelihoods and preserve the biocultural heritage of the local communities. In the case of Galicia, Spain, the traditional land-use system underwent rapid changes in the second half of the 20th century as a result of market integration, rural depopulation, and urban development. The government of Galicia has begun to develop strategies to identify, conserve, and promote traditional landscapes as a means of fostering regional development and identity. This mirrors the broader trend in Europe toward increasing the multifunctionality of landscapes and seeking regional solutions for regional problems (Vos and Meekes 1999).

\section{DRIVERS OF CHANGE IN SEPLS}

As the previous case studies suggest, SEPLs are landscapes purposively managed for the production of multiple ecosystem services. They contribute to local, national, and global economies, and their production and harvesting processes reflect social, political, and economic changes occurring at a larger scale. We proceed to analyze major drivers of change in SEPLs from sociopolitical, legal, economic, and socio-cultural perspectives. These societal drivers are interrelated and, taken together, may precipitate environmental changes and conversely provide a means of adapting to environmental changes. In analyzing the impact of these drivers on SEPLs, we have partly used FAO statistics to map the trend of production and export of agricultural commodities. This helps to better understand the interactions of these drivers with SEPLs and to infer implications for sustainable management of SEPLs.

Socio-political transformation: from state building to governance The modern process of nation-state building is a dominant driver in the transformation of SEPLs. From the perspective of political ecology, the state can be understood not only "as a site for the production of a definitive vision of (modern) nature," but also "as a political context within which struggles over the properties, meanings, and values of nature are being constantly expressed, managed, and partially regulated"(Whitehead et al. 2007:20). The 
13 countries we have reviewed represent different political and economic systems. However, most of these states have engaged in a kind of social engineering aimed at influencing popular attitudes, social behaviors, and resource management. Statesponsored social engineering projects often serve as a powerful agent of homogenization, uniformity, and market-driven standardization (Scott 1998). Some examples contained in the case studies include the pursuit of an agrarian utopia during the Khmer Rouge regime in Cambodia (1975-1979), the promotion of monocultural rice farming and large-scale irrigation in postcolonial Sri Lanka, the push for export-oriented agribusiness development in northeast Thailand, and the sedentarization processes in Kenya and China's Inner Mongolia Autonomous Region. These policy attempts have left a lasting effect on SEPLs. Policy makers have only recently begun to reassess development policies under the global agenda of good governance.

In the case of Cambodia, as Figure 1 shows, the political turmoil of the 1970s took a great toll on the production of Cambodia's staple food, rice. It was not until 1995-1996 that the country regained self-sufficiency in rice production (Nesbitt 1997). To improve food security and reduce poverty in Cambodia, bilateral, multilateral, and nongovernmental organizations have initiated a number of rural development programs since the early 1990s (Curtis 1998). Some useful lessons can be learned in terms of how to deliver and distribute program benefits more effectively with the engagement of local communities (Charnya et al. 2001). The establishment of commune/sangkat councils has provided a decentralized organizational structure to implement rural development programs such as community forestry. Although some constraints remain, such as lack of financial resources and limited capacity, commune councils have played an important role in the community forestry management process, which includes activities such as resolving land conflicts and coordinating with relevant institutions (Marady et al. 2012).

Fig. 1. Harvest area for paddy rice in Cambodia (ha). Data source: FAOSTAT (http://faostat.fao.org/).

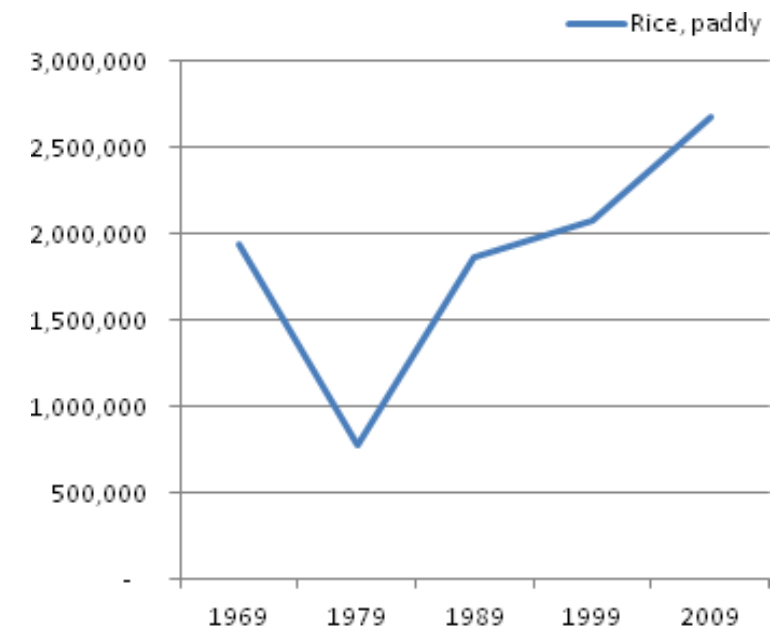

In Sri Lanka, as Figure 2 shows, there was a drop in the harvest area for all the major agricultural commodities, i.e., rice, tea, coconut, and natural rubber, between the late 1970s and the early 1990s, which coincided with the outbreak of civil war in the country. The Sri Lankan government has indicated the possibility of increasing crop production further because some areas in the former war zone have been converted into agricultural fields (Sirilal and Hull 2011). As shown in the case study, efforts have also been made to promote local food production as a step toward improving food and job security. Most of the homegarden products are kept for domestic consumption, whereas others, e. g., timber and cash crops, are sold for additional income at the market.

Fig. 2. Harvest area for major agricultural commodities of Sri Lanka (ha). Data source: FAOSTAT (http://faostat.fao.org/).

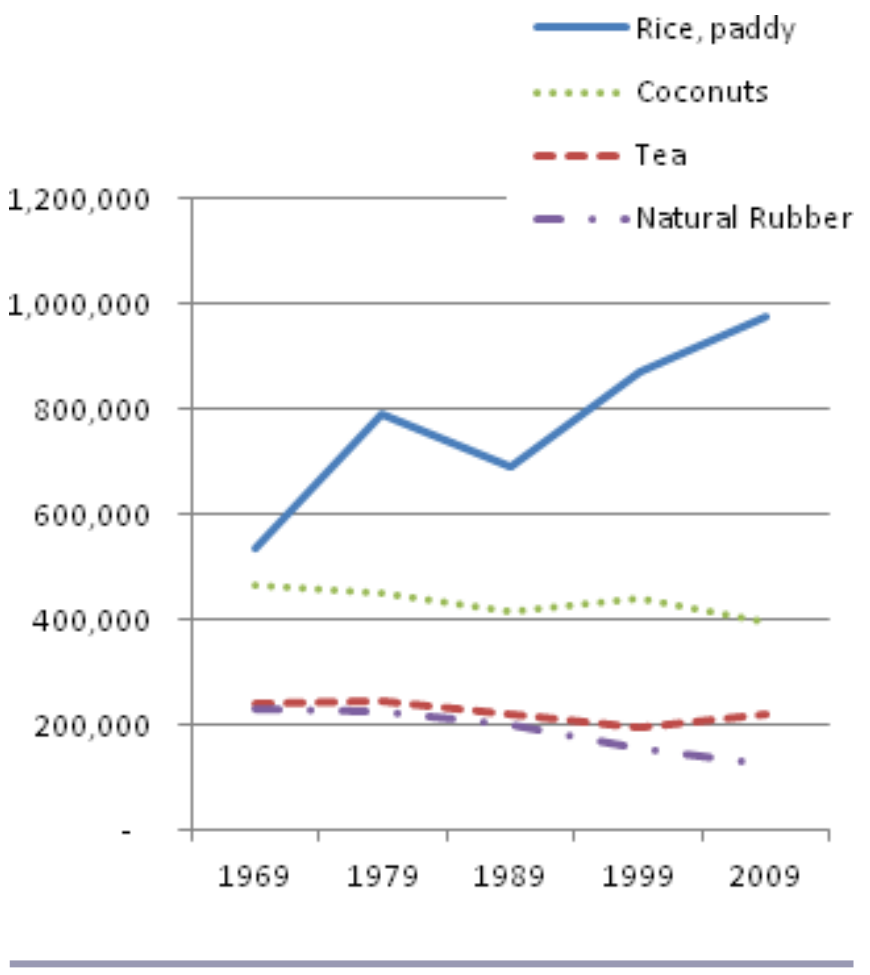

Legal rights and autonomy

A related theme arising from the case studies is about change in property rights regimes and its impact on the access, use, and conservation of natural resources. This has been manifested in the cases of common pool resources such as forests, watersheds, and pastures. With increased access of new users, common pool resources are now managed under complex regimes, which often lead to overexploitation, alienation of traditional users, and interuser conflicts (Steins and Edwards 1999). This is exemplified in the cases of Malawi, Thailand, and Kenya where the development of commercial fishing and other resource extraction industries has put much stress on traditional land-use practices (Nakayama 2010, KENWEB 2011, Ministry of Natural Resources and Environment, Thailand 2011). To address this problem, various stakeholders are working toward developing 
new institutional arrangements for the comanagement of common pool resources. Donor-supported legal reforms have also been carried out in the cases of Cambodia and Nepal to promote the devolution of forest-use rights to local communities (Adhikari 2011, Marady et al. 2012). It is pointed out, however, that the current efforts to structure devolution may not serve the purpose well because they often fail to respond to the driving forces and processes that have caused the initial disempowerment of the communities (Jodha and Bhatia 1998).

The pressure for legal reform also comes from civil society. The international indigenous rights movement, which has gained momentum since the $1980 \mathrm{~s}$, has been demanding territorial autonomy and respect for customary laws (Ivison et al. 2000, Sieder 2002, Xanthaki 2007). The movement has achieved positive results in the cases of the Mexican state of Oaxaca and the Philippines, where legal frameworks have been established for multiculturalism and indigenous rights (Matsuzaki and Wong 2010, Daguitan 2012). More recently, the government of Peru has also passed the Law on Prior Consultation with Indigenous Communities, i.e., Ley de Derecho a la Consulta Previa a los Pueblos Indígenas, which marks a historic step in recognizing the rights of indigenous peoples in Peru and their stake in the decision-making process for large-scale natural resource development projects (Nomi 2011).

\section{Economic globalization}

The process of market integration and trade liberalization has accelerated in the current era of globalization, which increasingly exposes SEPLs to external market forces. The challenge is how to create added value to the products of SEPLs to help them gain a competitive position in the value chains. The case of Galicia, Spain, illustrates that market integration has contributed to regional development on the one hand and the transformation of traditional agrarian landscapes and their main products on the other (Calvo-Iglesias et al. 2011). Although agricultural trade liberalization may have brought economic benefits to some countries, it remains unclear how much of these benefits are flowing back to SEPLs. Attempts made by the Kamba people in Kenya indicate efforts to leverage accessible market forces to improve local livelihoods (Morimoto et al. 2010). By contrast, as seen in the cases of the Potato Park in Peru and forest enterprises in Mexico, a community-led, rights-based approach has been introduced to partially decouple from broader market forces to retain sovereignty over land and resources (Argumedo and Wong 2010, Matsuzaki and Wong 2010).

Multilateral or regional economic groupings also contribute significantly to the determination of production systems. Trade regimes such as those under the World Trade Organization(WTO) enabled producers to gain preferential access to new markets, setting the stage for more specialized production systems. Take Thailand as an example. The country is a major producer and exporter of rice, natural rubber, and horticultural products such as fruits. Since the late 1990s, a jump in exports could be observed because Thailand became a WTO member in 1995 and recovered from the Asian financial crisis of 1997-1998 (Fig. 3). This trend is also in line with the Thai government's "kitchen of the world" policy (1999), which aims to promote the export of Thai agricultural products and to encourage the opening of Thai restaurants abroad. Conversely, the multilateral regime has brought in cheaper substitutes to dominant crops, making their cultivation untenable or uneconomical. For instance, the Tonga people of Chindozwa, Malawi, have begun to substitute their staple food cassava with maize following the influx of food aid (Nakayama 2010). It should be noted that an abrupt change to an economic partnership can also trigger changes in production systems, as with Cuba's move toward organic farming after the collapse of major trading partners in the Soviet Bloc (MugicaValdés et al. 2011).

Fig. 3. Major export commodities of Thailand (US\$1000).

Data source: FAOSTAT (http://faostat.fao.org/).

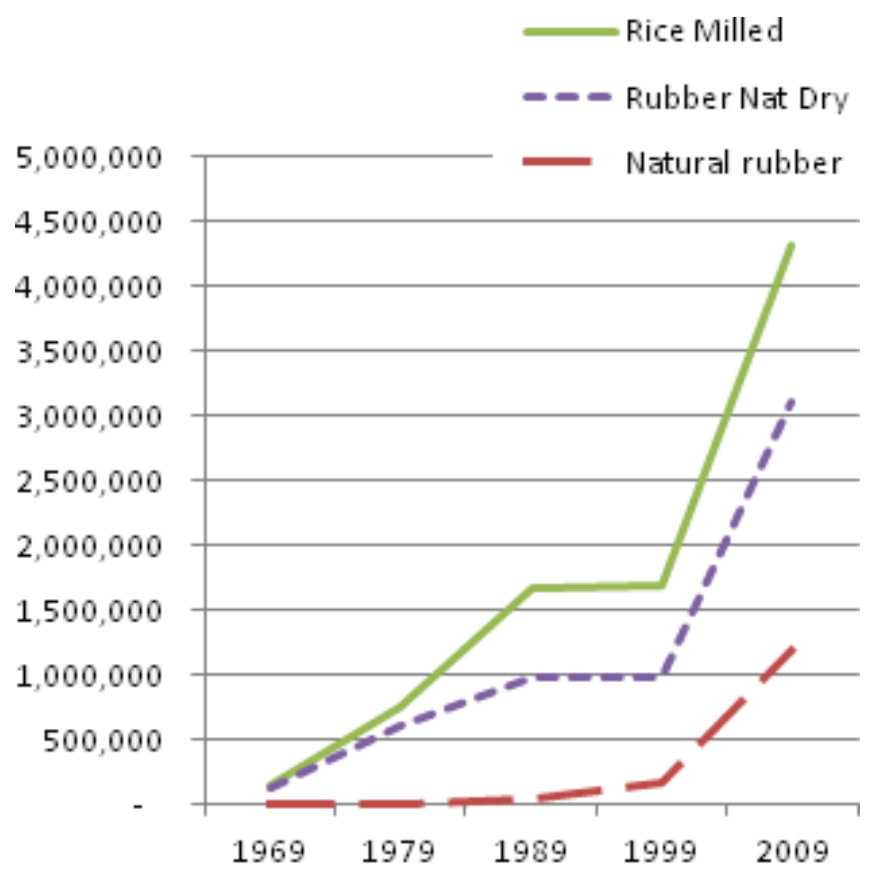

To revitalize SEPLs, market mechanisms such as branding and certification have been introduced to create awareness and effective demand for products from them. This is evidenced by the enthusiasm with which organic and specialty foods are traded. In Japan's Toyooka City, for example, as part of the effort to reintroduce Oriental White Storks, the municipal government has introduced the "flying stork" certification system to promote ricefarming practices free of, or with fewer, agrochemicals (Ohsako 2010). These certified organic products can be sold at higher prices in a niche or larger market, which helps contribute to rural revitalization especially in depopulated and aging regions of Japan. The case of Toyooka points to the fact that products and services of SEPLs could be better utilized to generate market value, which then needs to be transferred back to the maintenance of SEPLs.

\section{Demographic and socio-cultural changes}

Changes in demography and socio-cultural spheres also affect the changes in land use. The past few decades have seen a marked increase in productivity of conventional agriculture, which is characterized by the use of higher-yield varieties of crops, i.e., 
wheat, rice, and corn/maize, extensive irrigation schemes, inorganic fertilizers, agrochemicals, and fossil fuel-based farm machinery (UNEP 2011). In industrialized countries such as Japan and Spain, the postwar decline of the agricultural sector, in terms of both employment and its contribution to national income, has been, to some extent, compensated for by an increase in the productivity of major food commodities (Figs. 4 and 5). These countries are now grappling with the challenges of an aging population and labor shortage in the agricultural sector, as well as an increase in degraded and abandoned arable land. To address these problems, policy makers in Japan and Spain have introduced new laws and measures to revitalize rural areas and traditional landscapes, as mentioned in the case studies (Ohsako 2010, CalvoIglesias et al. 2011).

Fig. 4. The change in rice production and harvest area in Japan. Data source: FAOSTAT (http://faostat.fao.org/).

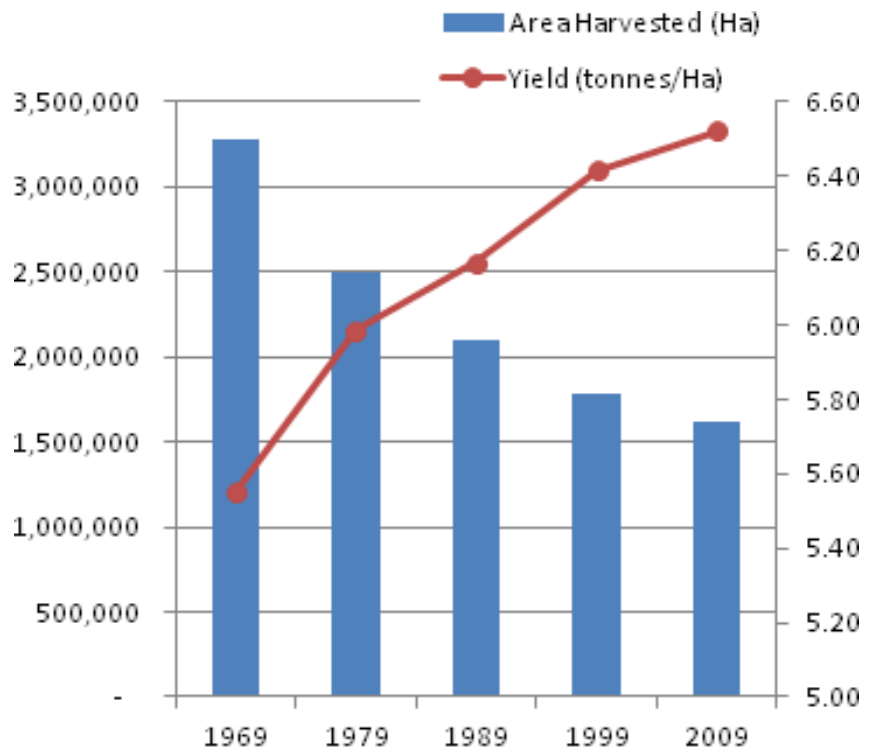

In developing countries such as Peru and Malawi, where SEPLs are still living traditions, many food-related cultures and values have been preserved and passed on through unique local expressions, e.g., ayllu in Peru and dendi in Malawi (Argumedo and Wong 2010, Nakayama 2010). In Kenya's Kitui District, the Kamba people have adapted traditional knowledge and local institutions to cope with droughts and meet their nutritional needs (Morimoto et al. 2010). However, in many other places such as China's Inner Mongolia, communities are grappling with the challenges of how to preserve cultural tradition and social cohesion in the face of development and market pressures (Liu et al. 2012). Policy makers are urged to pay closer attention to the role of traditional knowledge and practices in community development and natural resource management and to design future policies tailored to local contexts.
Fig. 5. The change in grape production and harvest area in Spain. Data source: FAOSTAT (http://faostat.fao.org/).

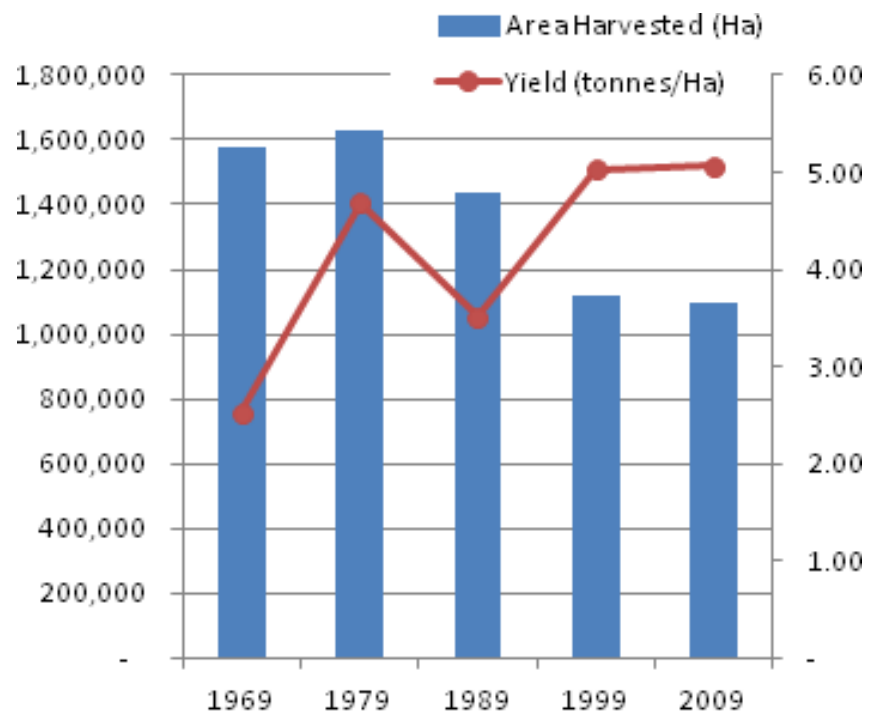

\section{IMPLICATIONS FOR BETTER MANAGEMENT}

It should be emphasized that the analysis we present does not argue for the conservation of SEPLs through museumification or for the sake of nostalgic romanticism. Rather, it seeks to identify innovative forms of landscape management that respect the needs and rights of local communities while creating added value to the products of SEPLs to help them achieve a more favorable position in the value chains. The challenge faced by policy makers lies in how to allocate resources and provide incentives to facilitate such efforts. Based on previous analysis, we provide the following suggestions on how to improve sustainable management of SEPLs.

First, the link between SEPLs and good governance needs to be strengthened. For instance, the case studies of Cambodia and Sri Lanka suggest that SEPLs contribute not only to food security but also to poverty alleviation and community development. Policy makers should recognize the socioeconomic values of SEPLs and incorporate these values into broader policy considerations. An attempt to mainstream SEPLs is being made through community development and knowledge management for the Satoyama Initiative (COMDEKS) project (http:// comdeksproject.com/), which is supported by the Ministry of the Environment, Japan, the Secretariat of the CBD, and the United Nations University and is implemented by the United Nations Development Programme. The project is scheduled to run for five years (2011-2016), during which small grants will be provided to local community organizations in pilot developing countries to support sustainable landscape management practices. It will share best practices and key lessons learned from on-the-ground activities and then use this knowledge for capacity building, replication in other parts of the world, and upscaling to subnational and national levels. 
Second, taking account of the various needs and priorities of natural resource users, there is a clear need to set in place new institutions comprising a consortium of relevant stakeholders to enable effective comanagement of SEPLs. This is exemplified by the case studies of common pool resources in Malawi, Thailand, and Kenya (Nakayama 2010, KENWEB 2011, Ministry of Natural Resources and Environment, Thailand 2011). Another important issue that needs to be addressed is how to harmonize traditional and modern systems of natural resource management. The externally designed, top-down formal arrangements tend to replace or disrupt customary laws and institutions. Although legal reforms have been carried out to re-empower local communities through devolution and better recognition of their rights, as in the cases of Cambodia, Nepal, Mexico, and the Philippines (Matsuzaki and Wong 2010, Adhikari 2011, Daguitan 2012, Marady et al. 2012), it remains difficult to rebuild community cohesion and resilience without revitalizing customary law and institutions. This is not to suggest the revival of traditional arrangements as they were in the past. What policy makers need to consider is how to develop an integrated natural resource management system to help communities better adapt to new socioeconomic circumstances.

Third, it is necessary to develop appropriate economic policies with a better understanding of their social-ecological implications throughout the value chain processes. As evident from the case studies, policy interventions in the agricultural sector usually function through economic incentives and disincentives, which are reflective of the trade dynamics of a country. The relevance of conventional incentive schemes such as subsidies is being reassessed in the light of evidence revealing their negative impact on the environment (ten Brink 2011). Given their reach, speed of adoption, and the long periods required to regain equilibrium in the event of drastic disturbances to the social-ecological systems, it is imperative that careful thought be given before formulating relevant economic policies.

In addition, the role of certification in advancing awareness about SEPLs and their products cannot be ignored, because their benefits are quite obvious for market capitalization as seen in the case of Toyooka, Japan (Ohsako 2010). Despite their good intentions, third-party certification schemes often tend to be expensive and beyond the capacity of local communities. Solutions such as participatory guarantee systems (May 2008) could be introduced to engage producers, consumers, and other key stakeholders in the design and operation of certification schemes to help them retain ownership and control of the process.

Finally, measures are needed to strengthen community social capital, which has been in decline because of demographic change, the disruption of customary land-use practices, and other factors as identified in the previous analysis. This requires policy makers to adopt a more tailored approach, instead of "one-size-fits-all," and to engage multiple stakeholders to promote better understanding of the value of SEPLs. In particular, it is important to enhance the economic benefits that local communities could gain from SEPLs so as to incentivize them to retain and observe their customary values and land-use practices, as seen in the case study of the Potato Park in Peru (Argumedo and Wong 2010). It is also important to incorporate local perspectives and traditional knowledge into community development plans. This helps not only to re-empower local communities but also to induce collective action in the management of SEPLs.

\section{CONCLUSION AND FUTURE STUDIES}

Although SEPLs is a relatively new term, the human-influenced landscapes under discussion have existed for a long time and have evolved in tandem with changes in socio-political, legal, economic, and socio-cultural spheres. The reason why this term has recently gained currency in conservation circles is that there is a need to look beyond protected areas to the management of larger landscapes and ecosystems. As a major proponent of SEPLs, the Satoyama Initiative is working with its global partners to promote sustainable use and management of natural resources and to strengthen the resilience of social-ecological systems. We have drawn on the existing case studies collected by the Satoyama Initiative to understand the underlying driving forces that have caused SEPLs to change. By doing so, we have aimed to identify gaps and inform policy makers and researchers about the issue areas that require further attention and investigation.

Future studies can focus on at least two areas. One is on best practices and enabling factors. Policy makers should incorporate SEPLs into broader policy considerations such as the Aichi Biodiversity Targets of the CBD, the Millennium Development Goals, climate adaptation strategies, and so forth. This would require an appropriate policy mix to channel resources into the revitalization and sustenance of SEPLs. Because not much work has been done so far in this area, one could look at the country case studies such as those generated from the COMDEKS project to extract some useful information.

Another area on which to focus would be ways to enhance the resilience of SEPLs. Some indicators have been developed to measure resilience in SEPLs (van Oudenhoven et al. 2011, Bergamini et al. 2013), which have attracted growing interest from policy makers, field practitioners, NGOs, and local communities. To help further this work, it would be useful to have a scenariobased characterization of SEPLs. By considering possible socialecological interactions, a typology of four scenarios can be identified (Fig. 6). These scenarios are conceptualized as part of a gradient. Scenario A refers to the case of well-managed SEPLs in which social and ecological benefits are both high. However, it is also likely to be the case that not much production occurs in situ, suggesting a high dependence on imported food and goods. Scenario B represents the case of overuse, in which social benefits are gained at the cost of ecological health. Scenario $C$ is associated with the case of underuse, which can be exemplified by the case of protected areas where biodiversity is high but people derive little direct benefit from it. Underuse or overexploitation of SEPLs could also lead to Scenario D, in which both ecosystem services and social well-being decline. Each of these scenarios pertains to a combination of drivers identified in the previous analysis. For instance, decisions related to the import of commodities or the types of crops to grow and related land uses are based on socio-political imperatives, legal obligations and privileges, market responses, and demographic changes. Future studies may further explore these scenarios and related drivers and develop specific measures to strengthen the resilience of SEPLs. 
Fig. 6. Typology of scenarios of social-ecological interactions.

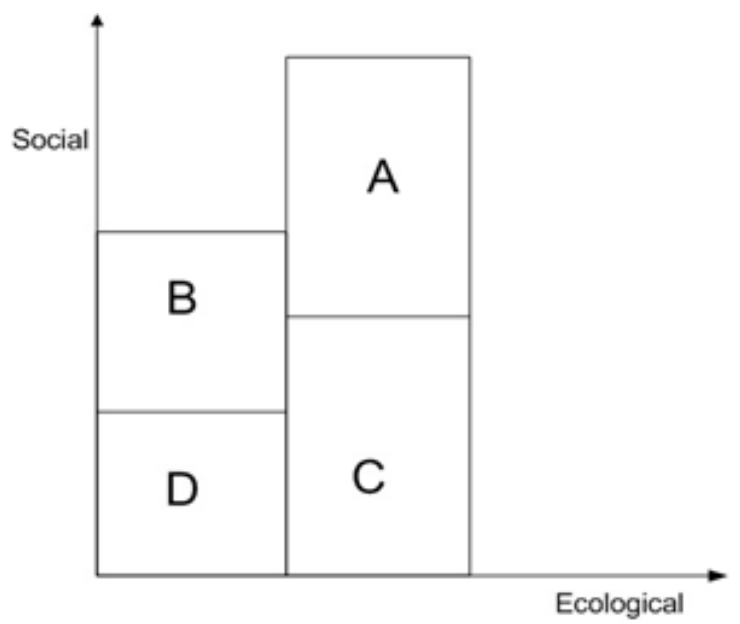

Finally, it should be mentioned that the term SEPLs is still evolving. For instance, the Satoyama Initiative has recently broadened the term to "socio-ecological production landscapes and seascapes (SEPLS)" to explicitly include seascapes as its target areas. Nevertheless, the core ideas behind the term remain unchanged, i.e., the development of socioeconomic activities such as agriculture, forestry, and fisheries, should align with natural processes and contribute to the vision of societies in harmony with nature. It remains to be seen how these ideas will be translated into reality in the years to come.

Responses to this article can be read online at: http://www.ecologyandsociety.org/issues/responses. $\mathrm{php} / 6283$

\section{Acknowledgments:}

The authors would like to thank Wataru Suzuki, Kaoru Ichikawa, and other colleagues from within and outside the United Nations University Institute for the Advanced Study of Sustainability (UNU-IAS), as well as the editor and anonymous reviewers for their constructive comments and suggestions. Thanks also go to members of the International Partnership for the Satoyama Initiative for providing the case studies and to Robert Blasiak of UNU-IAS for editing and commenting on the manuscript. The support of the Japan Society for the Promotion of Science to the first author is gratefully acknowledged. The views expressed in this paper are purely those of the authors and should not in any circumstances be regarded as stating an official position of the organizations involved. All errors and omissions remain those of the authors.

\section{LITERATURE CITED}

Adhikari, S. 2011. Community forestry in Nepal. Pages 23-31 in IPSI Secretariat, editor. IPSI case study booklet. United Nations
University Institute for the Advanced Study of Sustainability, Yokohama, Japan.

Argumedo, A., and B. Y. L. Wong. 2010. The ayllu system of the Potato Park (Peru). Pages 84-90 in C. Bélair, K. Ichikawa, B. Y. L. Wong, and K. J. Mulongoy, editors. Sustainable use of biological diversity in socio-ecological production landscapes. Background to the 'Satoyama Initiative for the benefit of biodiversity and human well-being.' Technical Series No. 52, Secretariat of the Convention on Biological Diversity, Montreal, Quebec, Canada. [online] URL: http://www.cbd.int/doc/ publications/cbd-ts-52-en.pdf

Bergamini, N., R. Blasiak, P. Eyzaguirre, K. Ichikawa, D. Mijatovic, F. Nakao, and S. M. Subramanian. 2013. Indicators of resilience in socio-ecological production landscapes (SEPLS). United Nations University Institute for the Advanced Study of Sustainability (UNU-IAS) Policy Report, UNU-IAS, Yokohama, Japan. [online] URL: http://www.ias.unu.edu/resource centre/ Indicators-of-resilience-in-sepls ev.pdf

Berkes, F., J. Colding, and C. Folke. 2003. Navigating socialecological systems: building resilience for complexity and change. Cambridge University Press, Cambridge, UK. http://dx.doi. org/10.1017/CBO9780511541957

Brown, J., N. Mitchell, and M. Beresford. 2005. The protected landscape approach: linking nature, culture and community. International Union for Conservation of Nature, Gland, Switzerland.

Calvo-Iglesias, M. S., G. Méndez-Martínez, and R. A. D\&\#237az-Varela. 2011. The Agras field system as a cultural landscape in Galicia (Spain). Pages 229-236 in IPSI Secretariat, editor. IPSI case study booklet. UUnited Nations University Institute for the Advanced Study of Sustainability, Yokohama, Japan.

Charnya, C., S. Pithou, S. Sovannarith, J. McAndrew, N. Sokunthea, P. Dorina, and R. Bidduplh. 2001. Learning from rural development programmes in Cambodia. Pages 285-346 in A. Straub, editor. Institutions, livelihoods and the environment: change and response in mainland Southeast Asia. Nordic Institute of Asian Studies, Copenhagen, Denmark.

Colfer, C. J. P., and D. Capistrano. 2005. The politics of decentralization: forests, people and power. Earthscan, London, UK.

Costello, L., and B. Vorsak. 2011. Natural resource management in the critical habitat of Western Siem Pang. Pages 69-77 in IPSI Secretariat, editor. IPSI case study booklet. United Nations University Institute for the Advanced Study of Sustainability, Yokohama, Japan.

Curtis, G. 1998. Cambodia reborn? The transition to democracy and development. Brookings Institution, Washington, D.C., USA.

Daguitan, F. 2012. Role of traditional knowledge in strengthening socio-ecological production landscapes. Pages 176-182 in IPSI Secretariat, editor. IPSI case study booklet. United Nations University Institute for the Advanced Study of Sustainability, Yokohama, Japan.

Davis, M. 2005. Forests and conflict in Cambodia. International Forestry Review 7:161-164. http://dx.doi.org/10.1505/ifor.2005.7.2.161 
Diego Quintana, R., L. Concheiro Bórquez, and R. Pérez Aviles. 1998. Peasant logic, agrarian policy, landmobility, and landmarkets in Mexico. Working Paper 21, University of Wisconsin-Madison, Madison, Wisconsin, USA.

Duraiappah, A. K., K. Nakamura, K. Takeuchi, M. Watanabe, and M. Nishi. 2012. Satoyama-satoumi ecosystems and human well-being: socio-ecological production landscapes of Japan. United Nations University Press, Tokyo, Japan.

Fisher, R. J. 2010. Devolution or persistence of state control? Pages 21-37 in C. Wittayapak and P. Vandergeest, editors. The politics of decentralization: natural resource management in Asia. Mekong, Chiang Mai, Thailand.

Folke, C. 2006. Resilience: the emergence of a perspective for social-ecological systems analyses. Global Environmental Change 16:253-267. http://dx.doi.org/10.1016/j.gloenvcha.2006.04.002

Fratkin, E. 1997. Pastoralism: governance and development issues. Annual Review of Anthropology 26:235-261. http://dx.doi. org/10.1146/annurev.anthro.26.1.235

Gonzalez, C. G. 2003. Seasons of resistance: sustainable agriculture and food security in Cuba. Tulane Environmental Law Journal 16:685-732.

Harvey, C. A., O. Komar, R. Chazdon, B. G. Ferguson, B. Finegan, D. M. Griffith, M. Martínez-Ramos, H. Morales, R. Nigh, L. Soto-Pinto, M. Van Breugel, and M. Wishnie. 2008. Integrating agricultural landscapes with biodiversity conservation in the Mesoamerican hotspot. Conservation Biology 22:8-15. http://dx.doi.org/10.1111/j.1523-1739.2007.00863.x

Iftekhar, M. S. 2006. Conservation and management of the Bangladesh coastal ecosystem: overview of an integrated approach. Natural Resources Forum 30:230-237. http://dx.doi. org/10.1111/j.1477-8947.2006.00111.x

Ivison, D., P. Patton, and W. Sanders. 2000. Political theory and the rights of indigenous peoples. Cambridge University Press, Cambridge, UK.

Jodha, N., and A. Bhatia. 1998. Community management of commons: re-empowerment process and the gaps. Crossing Boundaries: 7th Conference of the International Association for the Study of Common Property (Vancouver, British Columbia, Canada). International Association for the Study of Common Property, Bloomington, Indiana, USA. [online] URL: http:// www.snap-undp.org/lepknowledgebank/Public\%20Document $\% 20$ Library/ Community $\% 20$ Management $\% 20$ of $\% 20$ Commons $\% 20-\% 20$ Reempowerment $\% 20$ process $\% 20$ and $\% 20$ the $\% 20$ gaps.pdf

Kenya Wetlands Biodiversity Research Team (KENWEB). 2011. Promoting co-management of socio-ecological landscapes in flood dependent agroforestry, pastoral and fishery systems of eastwards flowing rivers of Eastern Africa through scientific research and indigenous knowledge. KENWEB, Nairobi, Kenya. [online] URL: http://satoyama-initiative.org/promoting-co-management-of-socioecological-landscapes-in-flood-dependent-agroforestry-pastoraland-fishery-systems-of-eastwards-flowing-rivers-of-eastern-africathrough-scientific-research-and-indig/

Khumsri, M., N. Sriputtnibondh, and W. Thongpun. 2005. Fisheries co-management in Lower Songkhram River Basin: problems and challenges. Pages 121-126 in Proceedings of the 7th
Technical Symposium on Mekong Fisheries (Ubon Ratchathani, Thailand, 15-17 November 2005). Mekong River Commission, Vientiane, Lao People's Democratic Republic. [online] URL: http://ns1.mrcmekong.org/download/free_download/ proceedings 7TechSym/paper9-fisheries-co-management.pdf

Li, W. J., S. H. Ali, and Q. Zhang. 2007. Property rights and grassland degradation: a study of the Xilingol pasture, Inner Mongolia, China. Journal of Environmental Management 85:461-470. http://dx.doi.org/10.1016/j.jenvman.2006.10.010

Liu, J., J. Harris, L. Zhao, H. Jiang, and F. Qian. 2012. Integrating community development with the management of grasslands at Ke'erqin Nature Reserve, Inner Mongolia, China. Pages 183-196 in IPSI Secretariat, editor. IPSI case study booklet. United Nations University Institute for the Advanced Study of Sustainability, Yokohama, Japan.

Marady, I., H. Sokla, and S. Mary. 2012. Role and involvement of the commune council in community forestry activities in Domnak Neak Ta Thmor Puan. Pages 9-15 in IPSI Secretariat, editor. IPSI case study booklet. United Nations University Institute for the Advanced Study of Sustainability, Yokohama, Japan.

Mathur, P. K., and P. R. Sinha. 2008. Looking beyond protected area networks: a paradigm shift in approach for biodiversity conservation. International Forestry Review 10:305-314. http://dx. doi.org/10.1505/ifor.10.2.305

Matsuzaki, K., and B. Y. L. Wong. 2010. Forest management through community-based forest enterprises in Ixtlán de Juárez, Oaxaca, Mexico. Pages 98-100 in C. Bélair, K. Ichikawa, B. Y. L. Wong, and K. J. Mulongoy, editors. Sustainable use of biological diversity in socio-ecological production landscapes. Background to the 'Satoyama Initiative for the benefit of biodiversity and human well-being.' Technical Series No. 52, Secretariat of the Convention on Biological Diversity, Montreal, Quebec, Canada. [online] URL: http://www.cbd.int/doc/publications/cbd-ts-52-en.pdf

May, C. 2008. PGS guidelines: how participatory guarantee systems can develop and function. International Federation of Organic Agriculture Movements, Bonn, Germany. [online] URL: http://www.ifoam.org/about ifoam/pdfs/PGS PDFs/

PGS Guidelines EN_Web.pdf

McKay, D. 2006. Rethinking indigenous place: Igorot identity and locality in the Philippines. Australian Journal of Anthropology 17(3):291-306. http://dx.doi.org/10.1111/j.1835-9310.2006.tb00065. $\underline{\mathrm{X}}$

Ministry of Natural Resources and Environment, Thailand. 2011. Local livelihood in the Lower Songkhram Basin. Pages 32-37 in IPSI Secretariat, editor. IPSI case study booklet. United Nations University Institute for the Advanced Study of Sustainability, Yokohama, Japan.

Mora, C., and P. F. Sale. 2011. Ongoing global biodiversity loss and the need to move beyond protected areas: a review of the technical and practical shortcomings of protected areas on land and sea. Marine Ecology Progress Series 434:251-266. http://dx. doi.org/10.3354/meps09214

Morimoto, Y., P. Maundu, D. Tumbo, and P. Eyzaguirre. 2010. How farmers in Kitui use wild and agricultural ecosystems to meet their nutritional needs (Kenya). Pages 67-72 in C. Bélair, K. 
Ichikawa, B. Y. L. Wong, and K. J. Mulongoy, editors. Sustainable use of biological diversity in socio-ecological production landscapes. Background to the 'Satoyama Initiative for the benefit of biodiversity and human well-being.' Technical Series No. 52, Secretariat of the Convention on Biological Diversity, Montreal, Quebec, Canada. [online] URL: http://www.cbd.int/doc/ publications/cbd-ts-52-en.pdf

Mugica-Valdés, L., M. Acosta-Cruz, and V. Anadón-Irizarry. 2011. Waterbird conservation promotes important energy flow between rice paddies and nearby Important Bird Areas in Cuba. Pages 78-83 in IPSI Secretariat, editor. IPSI case study booklet. United Nations University Institute for the Advanced Study of Sustainability, Yokohama, Japan.

Mukherjee, A., and C. K. Borad. 2004. Integrated approach towards conservation of Gir National Park: the last refuge of Asiatic Lions, India. Biodiversity \& Conservation 13:2165-2182. http://dx.doi.org/10.1023/B:BIOC.0000040009.75090.8c

Nakayama, S. 2010. Small scale catchment management in Malawi. [online] URL: http://satoyama-initiative.org/smallscale-catchment-management-in-malawi/

Nesbitt, H. J. 1997. Rice production in Cambodia. International Rice Research Institute, Manila, the Philippines. [online] URL: http://dspace.irri.org:8080/dspace/bitstream/10269/251/2/9712201007 content.pdf

Nomi, A. 2011. Peru passes historic law on prior consultation. Earthrights International, Washington, D.C., USA. [online] URL: http://www.earthrights.org/blog/peru-passes-historic-lawprior-consultation

Ohsako, Y. 2010. Reintroduction project of the Oriental White Stork for coexistence with humans in Satoyama areas, Hyogo, Japan. Pages 53-61 in IPSI Secretariat, editor. IPSI case study booklet. United Nations University Institute for the Advanced Study of Sustainability, Yokohama, Japan.

Ortiz, O. 2006. Evolution of agricultural extension and information dissemination in Peru: an historical perspective focusing on potato-related pest control. Agriculture and Human Values 23(4):477-489. http://dx.doi.org/10.1007/s10460-006-9014-4

Owuor, B., W. Mauta, and S. Eriksen. 2011. Sustainable adaptation and human security: interactions between pastoral and agropastoral groups in dryland Kenya. Climate and Development 3(1):42-58. http://dx.doi.org/10.3763/cdev.2010.0063

Phillips, A. 1998. The nature of cultural landscapes - a nature conservation perspective. Landscape Research 23(1):21-38. http:// dx.doi.org/10.1080/01426399808706523

Pushpakumara, D. K. N. G., A. Wijiesekara, and D. G. Hunter. 2010. Kandyan homegardens: a promising land management system in Sri Lanka. Pages 102-108 in C. Bélair, K. Ichikawa, B. Y. L. Wong, and K. J. Mulongoy, editors. Sustainable use of biological diversity in socio-ecological production landscapes. Background to the 'Satoyama Initiative for the benefit of biodiversity and human well-being.' Technical Series No. 52, Secretariat of the Convention on Biological Diversity, Montreal, Quebec, Canada. [online] URL: http://www.cbd.int/doc/ publications/cbd-ts-52-en.pdf
Scott, J. C. 1998. Seeing like a state: how certain schemes to improve the human condition have failed. Yale University Press, New Haven, Connecticut, USA.

Sieder, R. 2002. Multiculturalism in Latin America: indigenous rights, diversity and democracy. Palgrave Macmillan, New York, New York, USA.

Sirilal, R., and C. B. Hull. 2011. Sri Lanka says rice losses at 35 percent. Thomson Reuters Foundation, London, UK. [online] URL: http://www.trust.org/alertnet/news/sri-lanka-says-rice-lossesat-35-percent

Steins, N. A., and V. M. Edwards. 1999. Platforms for collective action in multiple-use common-pool resources. Agriculture and Human Values 16:309-315. http://dx.doi.org/10.1023/A:1007587330755

Sunam, R. K., M. R. Banjade, N. S. Paudel, and D. B. Khatri. 2010. Can bureaucratic control improve community forestry governance? An analysis of proposed Forest Act amendment. Discussion Paper Series 10:2, ForestAction Nepal, Kathmandu, Nepal. [online] URL: http://www.forestaction.org/app/webroot/ js/tinymce/editor/plugins/filemanager/files/5.\%20Sunam $\% 20$ et $\% 20 \mathrm{al} \%$ $20 \mathrm{Can} \% 20$ bureaucratic $\% 20$ control $\% 20$ improve $\% 20 \mathrm{CF} \% 20$ governance $\%$ 202010.pdf

Sunderlin, W. D. 2006. Poverty alleviation through community forestry in Cambodia, Laos, and Vietnam: an assessment of the potential. Forest Policy and Economics 8:386-396. http://dx.doi. org/10.1016/j.forpol.2005.08.008

ten Brink, P., editor. 2011. The economics of ecosystems and biodiversity in national and international policy making. The Economics of Ecosystems and Biodiversity, Geneva, Switzerland. [online] URL: http://www.teebweb.org/our-publications/teebstudy-reports/national-and-international-policy-making/

United Nations Environment Programme (UNEP). 2011. Towards a green economy: pathways to sustainable development and poverty eradication. UNEP, Nairobi, Kenya. [online] URL: http://www.unep.org/greeneconomy/greeneconomyreport/tabid/29846/ default.aspx

van Oudenhoven, F. J. W., D. Mijatovic, and P. B. Eyzaguirre. 2011. Social-ecological indicators of resilience in agrarian and natural landscapes. Management of Environmental Quality: An International Journal 22:154-173. http://dx.doi.org/10.1108/14777831111113356

Vos, W., and H. Meekes. 1999. Trends in European cultural landscape development: perspectives for a sustainable future. Landscape and Urban Planning 46(1-3):3-14. http://dx.doi. org/10.1016/S0169-2046(99)00043-2

Walker, B. H., J. M. Anderies, A. P. Kinzig, and P. Ryan. 2006. Exploring resilience in social-ecological systems through comparative studies and theory development: introduction to the special issue. Ecology and Society 11(1): 12. [online] URL: http:// www.ecologyandsociety.org/vol11/iss1/art12/

Whitehead, M., R. Jones, and M. Jones. 2007. The nature of the state: excavating the political ecologies of the modern state. Oxford University Press, Oxford, UK.

Wijisekara, A., and D. G. Hunter. 2010. The owita agroecosystem. Pages 113-115 in C. Bélair, K. Ichikawa, B. Y. L. Wong, and K. J. 
Mulongoy, editors. Sustainable use of biological diversity in socioecological production landscapes. Background to the 'Satoyama Initiative for the benefit of biodiversity and human well-being.' Technical Series No. 52, Secretariat of the Convention on Biological Diversity, Montreal, Quebec, Canada. [online] URL: http://www.cbd.int/doc/publications/cbd-ts-52-en.pdf

Wu, Z., and W. Du. 2008. Pastoral nomad rights in Inner Mongolia. Nomadic Peoples 12:13-33. http://dx.doi.org/10.3167/ np.2008.120202

Xanthaki, A. 2007. Indigenous rights and United Nations standards: self-determination, culture and land. Cambridge University Press, Cambridge, UK. http://dx.doi.org/10.1017/ CBO9780511494468 